\title{
Development of Online Learning Video for Blended Learning in Teletraffic Course
}

\author{
Rudy Fernandez ${ }^{1 *}$ Eka Putra Waldi ${ }^{1}$ \\ ${ }^{1}$ Electrical Engineering Department, Universitas Andalas, Limau Manis, Padang 25166, Indonesia \\ ${ }^{*}$ Corresponding author. Email: rfernandez@eng.unand.ac.id
}

\begin{abstract}
Teletraffic is an optional course for students of the Electrical Engineering Department in Universitas Andalas. The course used to delivered in offline learning mode and now is developed to be in blended learning mode. This article is aimed at describing the development of learning videos as a media in the blended learning class. The objective of the research is to identify the perception of the students toward the videos developed and used in Teletraffic course. The study is conducted at the Teletraffic class of Electrical Engineering Department at Andalas University. The data are collected by giving a questionnaire to the students. The students are evaluating the learning videos based on their perception. The analysis uses a qualitative descriptive method which is done by interpreting the collected data. The result of the study is presented descriptively.
\end{abstract}

Keywords: Blended learning, Distance learning, Learning video, E-learning

\section{INTRODUCTION}

Teletraffic Course is an optional course in the Curriculum of Electrical Engineering Department in Universitas Andalas (Unand). The course is conducted in the $7^{\text {th }}$ semester. All student in the department has to take the required courses, which are Probability and Statistic course and Telecommunication network before taking Teletraffic course [1].

The course is developed to be delivered in blended learning mode in this academic year (2020/2021). Blended learning is a form of a learning system that combines synchronous and asynchronous learning strategy in terms of creating a learning experience to achieve optimal outcome learning. An asynchronous learning strategy is a form of elearning which is based on information and communication technology for learning purposes that can be accessed by students anytime and anywhere [2].

The e-learning uses various technological tools that are either web-based, web-distributed or web-capable for the purposes of education [3]. This technology-based learning provides learning materials that are delivered electronically to remote learners over a computer network. It means that there are no printed learning materials. This learning is depending on technology which acts as a facilitator in the learning process.
The use of technology allows the learning process to be in the distance. Distance education refers to a mode of delivering a course of study in which the majority of communication between teachers and students occurs non contiguously, and the two-way communication between teacher and student necessary for the educational process is technology-mediated [4].

Distance Learning has the following characteristics:

(1) separation of educators and learners during the learning process, (2) educational institutions that have an essential role in the planning and development of learning materials,

(3) the use of various learning media, (4) the availability of indirect two-way communication, namely through media,

(5) limited frequency of classroom or group learning [5]. Learning materials represent the figure of the lecturer, and its existence can be said to be the only medium that allows students to study independently and autonomously. Therefore, learning materials play an important role in the distance learning process.

In this research, some of the learning topics in the course are developed to be learning videos. The multimedia learning materials are used because according to Kroehnert Theory, the more senses involved in the learning process, then the learning process will become more effective. 


\section{METHODS}

The research is conducted in Teletraffic Course at the Electrical Engineering Department of Andalas University. Online session in blended learning needs learning videos as teaching media for the students.

Normally in offline session, there are 14 learning topics. Four out of 14 topics are chosen to be the topics in the learning videos for the online session. The videos are designed to meet the requirement regulated by LP3M.

The learning videos are put on youtube. The links are posted in I Learn as teaching and learning platform in Universitas Andalas.

The students who attend the course will be given a questionnaire to evaluate the learning videos. The questionnaire measure the level of student perception toward the videos. Mainly, there are two categories to be measured in the questionnaire. They are video quality category and video content category. In the video quality category, there are 4 statements which are video easy to access, video sound quality, video image quality and written material readable. While in the video content category, there are 5 statements which are video support in learning, examples are relevant to the material, a moderate level of exercise, clear instruction for doing exercise and exercise helping to get a better understanding.

On each statement in each category, the student will choose four given options which are poor, fair, satisfactory and very good based on their perceptions. The questionnaire uses the google form as a tool for collecting the data.

The analysis is done by sorting the data based on the chosen option in each statement. Next, the percentage of the student responses for every category is calculated. Finally, the result of the analysis is descriptively presented

\section{RESULTS AND DISCUSSION}

The questionnaire used to evaluate the developed learning videos was filled in by 47 students. The result of the questionnaire for video quality category with four statements can be seen in figure $1,2,3$ and 4 .

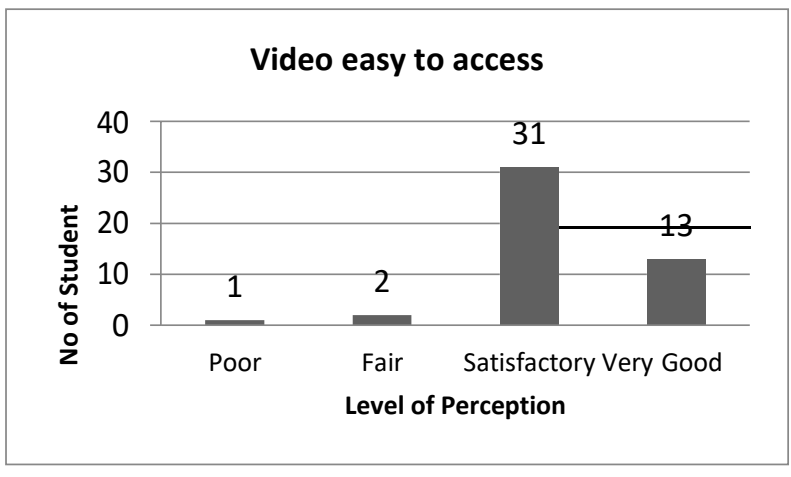

Figure 1 The number of student responses on the first statement of the first category

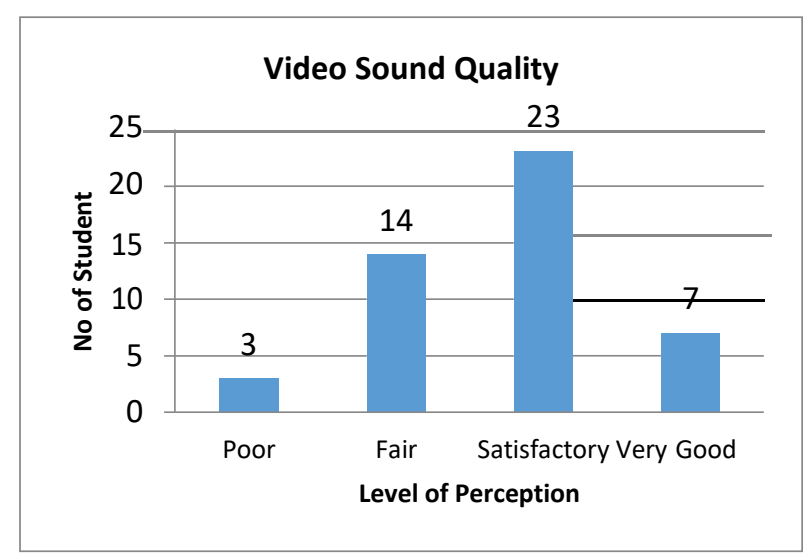

Figure 2 The number of student responses on the second statement of the first category

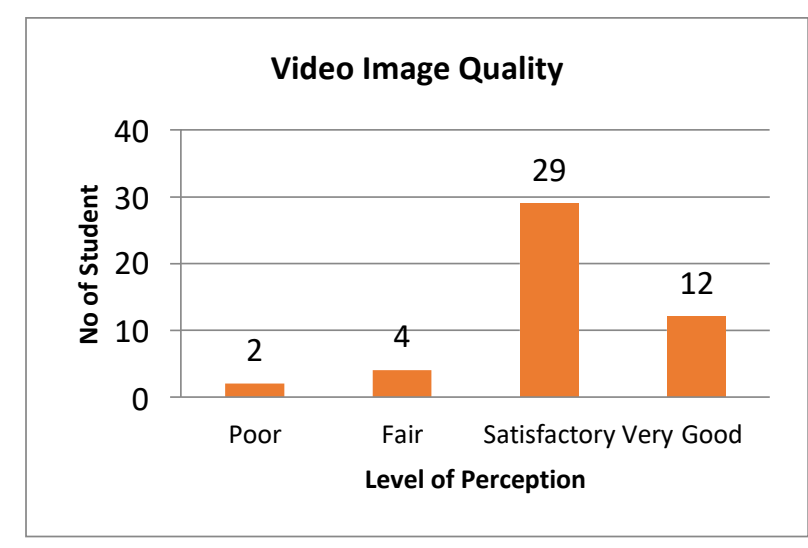

Figure 3 The number of student responses on the third statement of the first category 


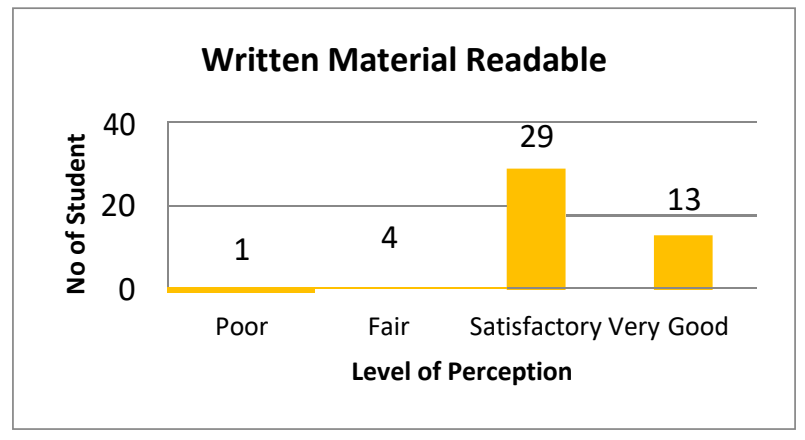

Figure 4 The number of student responses on the fourth statement of the first category

Based on the figures above, it can be stated that there are three out of four statements answered at least "satisfactory" by the number of students above 40 students. They are video easy to access (44 students), video image quality (41 students) and written material readable (42 students). While in video sound quality statement, only 30 students gave "satisfactory" at least for the answer.

In the answer "Poor" for every statement related to video quality, there are 3 people at most. The highest number of "fair" answer held by the sound quality video statement as many as 14 students. While in the other three statements selected by 4 people at most.

The result of the questionnaire for video content category with five statements can be seen in figure 5, 6, 7, 8 and 9 .

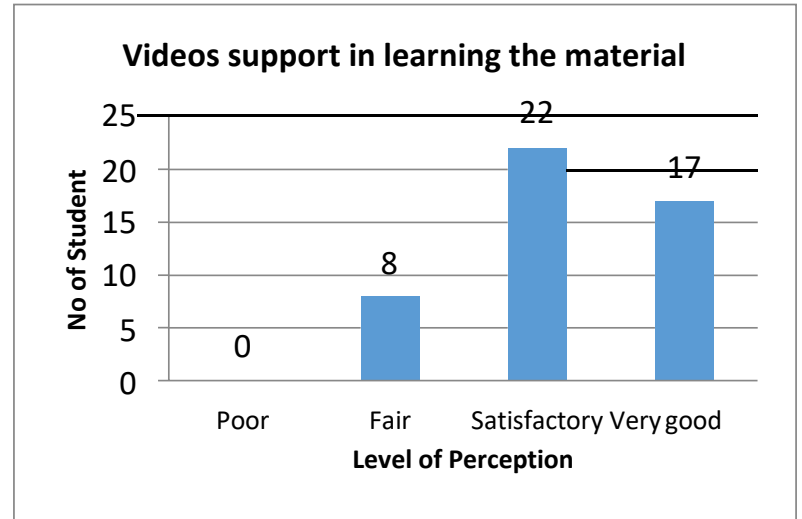

Figure 5 The number of student responses on the first statement of the second category

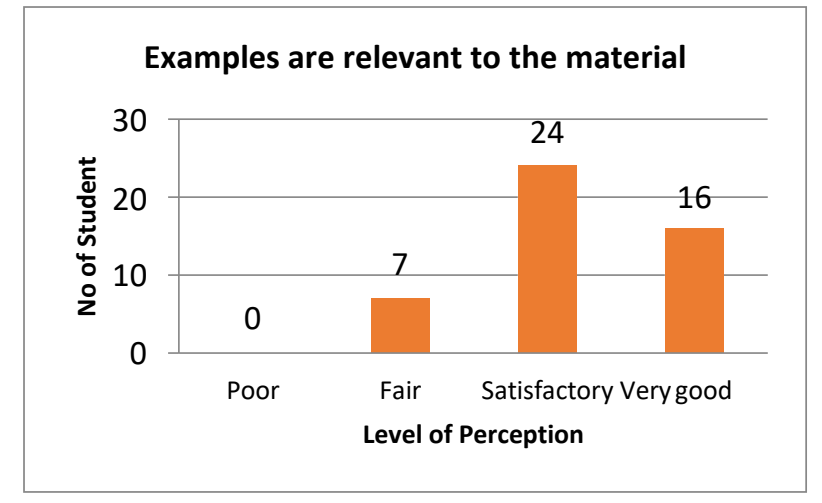

Figure 6 The number of student responses on the second statement of the second category

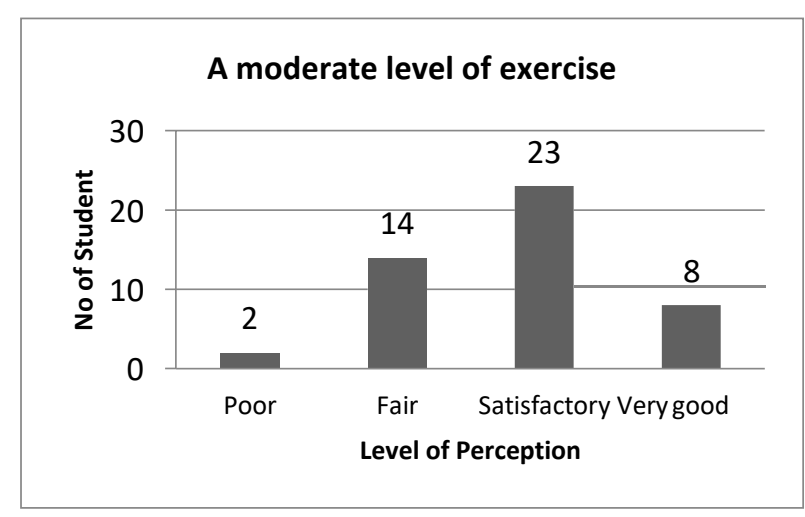

Figure 7 The number of student responses on the third statement of the second category

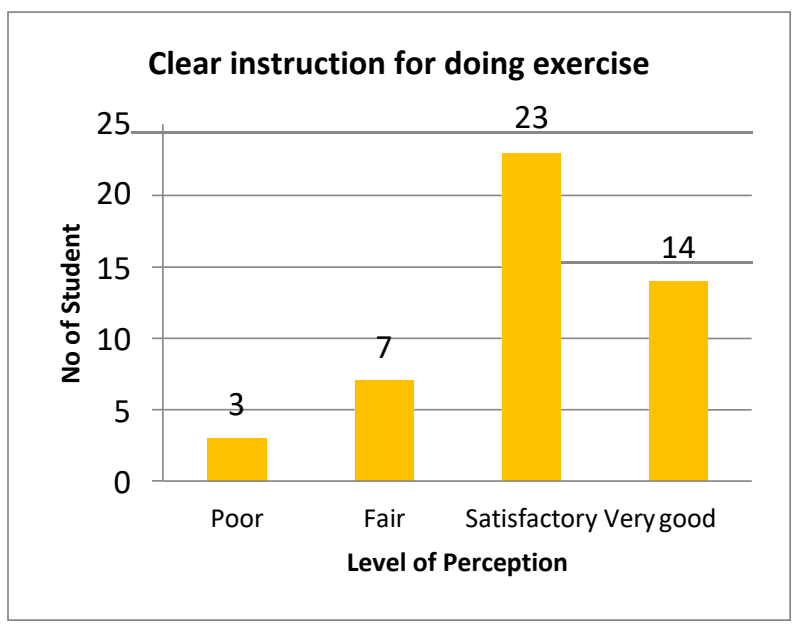

Figure 8 The number of student responses on the fourth statement of the second category 


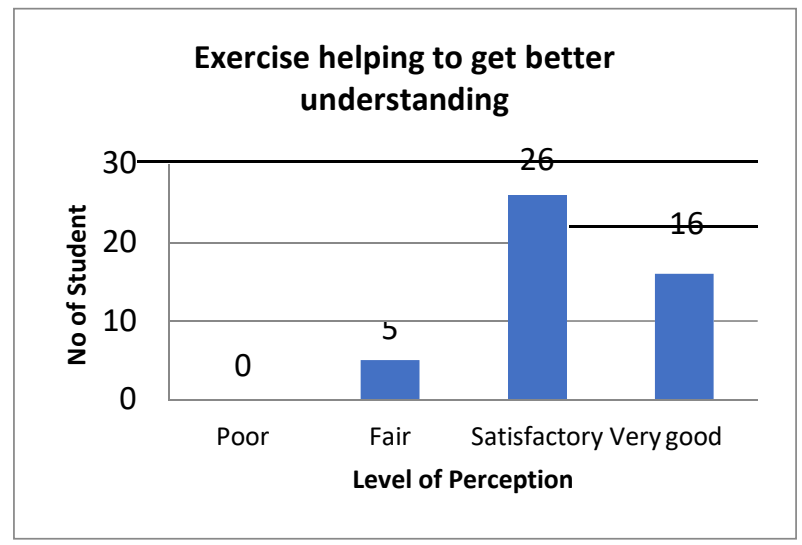

Figure 9 The number of student responses on the fifth statement of the second category

Based on the figures 5 - 9 for video content category, it can be stated that there are three out of five statements answered at least "fair" by students. They are video support in learning the material; examples are relevant to the material and exercise helping to get a better understanding. A moderate level of exercise is considered by 2 students and a clear instruction statement for doing exercise as many as 3 students for "poor" answer. In the "satisfactory" answer to each statement related to video content answered by above 30 students.

All of the responses to the questionnaire is converted into percentage and presented in one figure for each category. Percentage in video quality category and video content category is presented in figure 10 and 11, respectively.

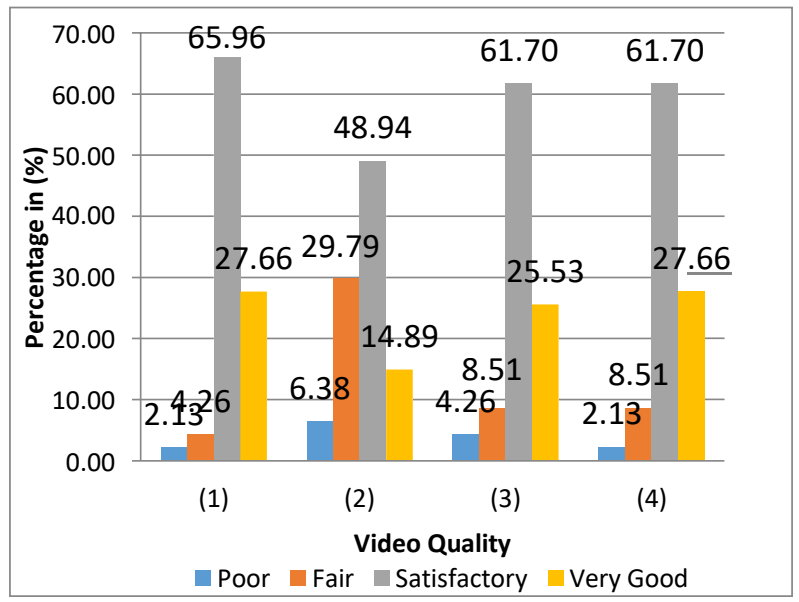

Figure 10 The percentage of student responses for all of the statement in the first category

There is $59.57 \%$ on average that answer "satisfactory" and becoming $83.46 \%$ on average after including the answer "very good" for video quality category in figure 10 .

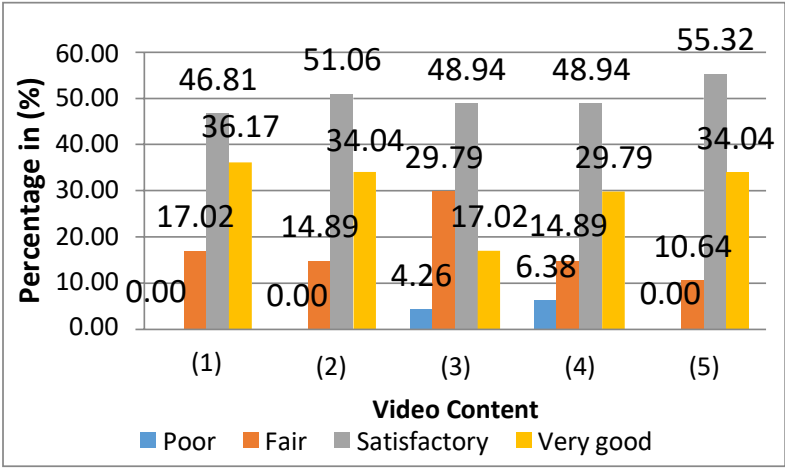

Figure 11 The percentage of student responses for all of the statement in the second category

Figure 11 shows that there is $50.21 \%$ on average choose "satisfactory" as the answer and becoming $80.42 \%$ on average if the answer "very good" included for video content category.

According to the average percentage for both category which is $81.94 \%$, the development of the learning video for Teletraffic course is quite promising.

\section{CONCLUSION}

The study concluded that development of the learning video as a media for blended learning on Teletraffic course has been responded by averagely $81.94 \%$ of the students with a response "satisfactory" and "very good" based on the questionnaire data. It means that learning videos are relatively acceptable for the class.

\section{ACKNOWLEDGMENT}

This work was supported by PPBL - LP3M Universitas Andalas Grant, 2020.

\section{REFERENCES}

[1] Kurikulum Program Studi Sarjana Teknik Elektro Tahun 2016.

[2] Peraturan Menteri Pendidikan dan Kebudayaan Republik Indonesia No 109 Tahun 2013 tentang Penyelenggaraan PJJ pada Pendidikan Tinggi.

[3] Nichols, M. A Theory for eLearning. Educational Technology \& Society, 1-10, 2003.

[4] Maxwell, L. Integrating Open Learning and Distance Education. Educational Technology, 4348, 1995.

[5] Asandhimitra, dkk. Pendidikan Tinggi Jarak Jauh. Jakarta: Pusat Penerbitan Universitas Terbuka. 2004. 